\title{
Letter
}

\section{Antifungal prophylaxis in critically ill patients}

\author{
Luciano Silvestri ${ }^{1}$, Durk F Zandstra ${ }^{2}$, Hendrick KF van Saene ${ }^{3}$, Andy J Petros ${ }^{4}$, \\ Sujatha Thyagarajan ${ }^{5}$, Miguel A de la Cal ${ }^{6}$ and Corrado Thomann ${ }^{1}$
}

\begin{abstract}
${ }^{1}$ Department of Emergency, Unit of Anaesthesia and Intensive Care, Presidio Ospedaliero, Via Vittorio Veneto 171, 34170 Gorizia, Italy ${ }^{2}$ Department of Intensive Care, Onze Lieve Vrouwe Gasthuis, Oosterpark 9, 1091 AC Amsterdam, The Netherlands ${ }^{3}$ Department of Medical Microbiology, University of Liverpool, Duncan Building, Daulby Street, Liverpool L69 3GA, UK ${ }^{4}$ Paediatric and Neonatal Intensive Care Unit, Great Ormond Street Children's Hospital, Great Ormond Street, London WC1N 3JH, UK ${ }^{5}$ Department of Intensive Care, Alder Hey Children's Hospital, Eaton Road, Liverpool L12 2AP, UK

${ }^{6}$ Intensive Care Unit, University Hospital, Carretera de Toledo km 12,500, 28905 Getafe, Madrid, Spain
\end{abstract}

Corresponding author: Luciano Silvestri, lucianosilvestri@yahoo.it

Published: 13 June 2008

This article is online at http://ccforum.com/content/12/3/420

(C) 2008 BioMed Central Ltd

See related research by van Till et al., http://ccforum.com/content/11/6/R126
Critical Care 2008, 12:420 (doi:10.1186/cc6906)

\section{Competing interests}

The authors declare that they have no competing interests.

\section{References}

1. van Till JWO, van Ruler O, Lamme B, Weber RJP, Reitsma JB, Boermeester MA: Single-drug therapy or selective decontamination of the digestive tract as antifungal prophylaxis in critically ill patients: a systematic review. Crit Care 2007, 11:R126.

2. Silvestri L, van Saene HKF, Milanese M, Gregori D: Impact of selective decontamination of the digestive tract on fungal carriage and infection. Systematic review of randomized controlled trials. Intensive Care Med 2005, 31:898-910.

3. van Saene HKF, Silvestri L, Petros A, Viviani M, de la Cal MA, Zandstra DF: Comment on 'Prevention of severe Candida infections in non-neutropenic, high-risk, critically ill patients' by Garbino et al. Intensive Care Med 2003, 29:1192-1193.

van Till and colleagues assessed yeast colonisation, lumping together 'positive yeast cultures obtained from sputum, stool, urine and/or wound' [1]. The majority of SDD trials reported positive yeast cultures obtained from surveillance cultures of throat and rectal swabs, whilst the SAP studies mainly assessed positive yeast cultures obtained from diagnostic samples including lower airway secretions, urine and wound fluid. Grouping together surveillance and diagnostic cultures may be misleading in interpreting the efficacy of antifungal interventions.

van Till and colleagues' review demonstrated a nonsignificant $41 \%$ reduction in candidemia by SDD and a $68 \%$ significant reduction by SAP [1]. The authors concluded that SAP prevents candidemia, whilst SDD does not. We believe that van Till and colleagues evaluated two different populations, as the candidemia rates in the control individuals were $3.79 \%$ and $1.69 \%$ for SAP and SDD, respectively. A larger sample size is almost certainly needed for SDD to demonstrate a significant reduction in candidemia [3].

$\mathrm{SAP}=$ single-drug prophylaxis $\mathrm{SDD}=$ selective decontamination of the digestive tract. 